Teologia i Moralność, Volumen 15(2020), numer 2(28)

doi: 10.14746/tim.2020.28.2.09

ORCID: 0000-0002-9173-5891

KRZYSZTOF SMYKOWSKI

Katolicki Uniwersytet Lubelski Jana Pawła II

\title{
Zależność przedsoborowej myśli teologicznomoralnej od refleksji prawnej i prawnokanonicznej. Analiza na podstawie kwestii relacji czlowieka do zwierząt ${ }^{1}$
}

Od początku wyodrębnienia teologii moralnej jako samodzielnej gałęzi refleksji teologicznej dziedzina ta była dość ściśle związana z zagadnieniami prawnymi i prawnokanonicznymi. Nie może to dziwić, gdyż mimo oczywistych różnic prawo (tak świeckie, jak i kanoniczne) oraz moralność mają charakter normatywny, a ich podmiotem jest człowiek. Różnice można dostrzec w sposobie argumentacji i motywacji. Prawo ze swej istoty ma charakter minimalistyczny, wyznaczając granice zachowań społecznie akceptowalnych. Moralność z kolei powinna wskazywać jakiś ideał, do którego człowiek ma dążyć. W pewnym momencie refleksja teologicznomoralna bardzo zbliżyła się do prawa, gubiąc w dużej mierze swoją tożsamość. Przed Soborem Watykańskim II dominacja prawa była tak silna, że teologię moralną określano mianem duszpasterskiego wykładu prawa kanonicznego (Wróbel 2016, 122). Niektórzy prekursorzy dwudziestowiecznej odnowy teologii moralnej zwykli nazywać ją także „bękartem etyki stoickiej i Kodeksu Prawa Kanonicznego” (Greniuk 1998, 76-77). Znane było wreszcie powiedzenie moralista non canonista nihil valet ${ }^{2}$ (Palazzini 1968, 478).

Celem niniejszego artykułu będzie ukazanie na przykładzie zagadnienia relacji człowieka do zwierząt zależności konkluzji obecnych w wybranych przedsoborowych podręcznikach teologii moralnej od obowiązujących wów-

\footnotetext{
${ }^{1}$ Praca powstała w wyniku realizacji projektu badawczego „Kształtowanie się świadomości obowiązków człowieka wobec zwierząt w podręcznikach teologii moralnej przełomu XIX i XX wieku - kwerenda" o nr 2018/02/X/HS1/01888 finansowanego ze środków Narodowego Centrum Nauki w ramach konkursu Miniatura-2.

${ }^{2}$ Teolog moralista, niebędący kanonistą (niemający gruntowej znajomości prawa kanonicznego), na nic się nie przyda.
} 
czas przepisów prawa kanonicznego i świeckiego. W tym celu analizie zostało poddanych kilkanaście podręczników reprezentujących nurty alfonsjański, neotomistyczny i chrystocentryczny oraz szereg leksykonów.

\section{Zależność od prawa świeckiego}

Opracowania teologicznomoralne powstałe w czasie poprzedzającym odnowę soborową wyraźnie odwołują się do przepisów prawa świeckiego. Ten wpływ jest szczególnie widoczny w dostosowaniu poszczególnych edycji tego samego podręcznika do ustawodawstwa kraju, do którego obywateli był skierowany. Jako jeden z przykładów można podać dzieło Heriberta Jonego OFMCap. Już sam tytuł tłumaczenia włoskiego wyraźnie zaznacza, że opracowanie zostało dostosowane do przepisów włoskiego i szwajcarskiego kodeksu cywilnego (Jone 1949). Różnice widać także w zawartości treściowej poszczególnych rozdziałów. Włoska edycja obszernie omawia kwestie związane z nabywaniem prawa własności poszczególnych gatunków zwierząt (gołębi, królików, ryb, pszczół), które uciekły spod pieczy właściciela (Jone 1949, 225-226), podczas gdy angielska całkowicie pomija to zagadnienie, ograniczając się do przywołania wyłącznie zasad ogólnych (Jone 1959, 173-174). Takich przykładów można by przywołać zdecydowanie więcej.

Zagadnieniem związanym z tematyką zwierząt, które jest omawiane najczęściej i najdokładniej niemal we wszystkich podręcznikach czy leksykonach, jest kwestia rodzajów zwierząt. Wyjątkiem w tym względzie są jedynie najbardziej syntetyczne kompendia teologii moralnej, które pomijają te analizy (Szczeklik 1906). Moraliści są w tym wypadku zgodni i wyróżniają trzy grupy zwierząt. Są to zwierzęta domowe, oswojone i dzikie. Do pierwszej grupy należą zwierzęta, które mają właściciela i ze swej natury są związane z człowiekiem. Zwierzęta oswojone są zdolne do życia w naturze, jednak zostały pozbawione przez człowieka wolności i są wykorzystywane w różnych sferach gospodarki. Wreszcie zwierzęta dzikie korzystają z naturalnej wolności, nie są poddane ludzkiemu panowaniu i jako takie nie stanowią niczyjej własności (Vermersch 1928, 356-357; Prümmer 1928, 41-42; Merkelbach 1959, 211-214; Smykowski 2014, 79-80).

Wpływ prawa stanowionego widoczny jest szczególnie mocno w przypadku zagadnienia nabywania prawa własności zwierząt. W tej kwestii autorzy podręczników są także zgodni. Przywołany wyżej podział stanowił dla teologów moralistów podstawę do sformułowania doktryny na temat nabywania i trwania prawa własności do poszczególnych typów zwierząt. Zwierzęta domowe oraz ich potomstwo należą zawsze do prawowitego właściciela. Zwierzęta oswojone także należą do właściciela, jednak tylko dopóki nie odzyskają 
pierwotnej wolności, uciekając od niego lub do niego nie powracając. Dzieje się tak także wtedy, gdy staje się on moralnie niezdolny do sprawowania kontroli nad swoimi zwierzętami lub gdy zaprzestaje ich hodowli. Zwierzęta dzikie zasadniczo nie są niczyją własnością. Na mocy zatem zasad ogólnych nabywania własności każdy może stać się ich posiadaczem (Noldin 1955, 356-357; Pighi i Grazioli 1946,103-105; Smykowski 2014, 79-80).

Konkluzje te są wynikiem bardzo dobrej znajomości przepisów zawartych w kodeksach cywilnych państw europejskich, które zostały uchwalone na przełomie XIX i XX wieku (wiele $\mathrm{z}$ tych aktów prawnych w formie znowelizowanej obowiązuje do chwili obecnej). Zasługą autorów analizowanych opracowań jest natomiast uogólnienie szczegółowych przepisów prawa cywilnego dotyczących kwestii nabywania prawa własności różnych rodzajów zwierząt i syntetyczne ich sformułowanie.

Oprócz przytoczenia zasad ogólnych wielu moralistów przedsoborowych podejmuje się rozważenia szeregu zagadnień szczegółowych. W zasadzie podręczniki alfonsjańskie i neotomistyczne nie formułują oryginalnych rozwiązań kwestii mogących stać się przedmiotem dylematów moralnych, lecz powtarzają i niekiedy komentują przepisy prawa cywilnego. W tym miejscu można dostrzec pewne rozbieżności. Wynikają one z faktu, że dla poszczególnych moralistów podstawą formułowania wniosków były przepisy obowiązujące w innych państwach.

Najwięcej uwagi poświęcono kwestii własności zwierząt oswojonych, które uciekły bądź z innego powodu nie znajdują się już w pieczy właściciela. Konkluzje moralistów są w tym wypadku zróżnicowane, co wynika z rozwiązań prawnych przyjętych $\mathrm{w}$ większości kodeksów cywilnych państw europejskich. Prawodawstwo włoskie (Codice Civile Italiano 1942, art. 925; por. także Onida 2009, 525) i hiszpańskie (Código Civil 1889, art. 612) zgodnie uznawało możliwość podjęcia poszukiwań przez właściciela w ciągu 20 dni od ucieczki zwierzęcia. Dopiero po upływie tego czasu zwierzę stawało się rzeczą niczyją i tym samym mogło zostać wzięte w posiadanie przez kogokolwiek. Podręczniki powstałe w kręgu włoskim (Jone 1949, 225) i hiszpańskim (Gury i Ferreres 1910, 422) przyjmują te rozwiązania prawne i ich przestrzeganie sytuują w kategorii powinności moralnej. Odmiennie sytuacja wyglądała w kręgu oddziaływania prawa niemieckiego (Bürgerliches Gesetzbuch 1896, art. 960) i szwajcarskiego (Codice Civile Svizzero 1907, art. 719). W tych państwach obowiązywała zasada, że właściciel powinien natychmiast podjąć się poszukiwania zaginionego zwierzęcia, aby zachować jego własność. To unormowanie znajduje odzwierciedlenie $\mathrm{w}$ podręcznikach adresowanych do odbiorców z tych państw (Vermeersch 1928, 358-359).

Wpływ ustawodawstwa świeckiego jest widoczny także w kwestii własności roju pszczelego, który opuścił ul znajdujący się na terenie należącym 
do jego właściciela. Prawodawstwo włoskie (Codice Civile Italiano 1942, art. 924) i hiszpańskie (Código Civil 1889, art. 612) pozwalało ścigać ten rój przez dwa dni. Jego właściciel miał nawet prawo wejścia na prywatny teren w celu odzyskania swojej własności. Po upływie tego czasu zwierzęta przechodziły na własność tej osoby, do której należał teren, na którym znalazły schronienie. Identyczne rozstrzygnięcia spotkać można w opracowaniach teologicznomoralnych wydanych we wspomnianych krajach (da S. Mauro 1962, 232; Jone 1949, 225; Pighi i Grazioli, 104). Odmienne rozwiązane analizowanego zagadnienia przyjął ustawodawca niemiecki (Bürgerliches Gesetzbuch 1896, art. 961) i szwajcarski (Codice Civile Svizzero 1907, art. 719, 725). Brak natychmiastowej reakcji ze strony właściciela był traktowany jak zrzeczenie się prawa własności. Nie może zatem dziwić, że opracowania teologicznomoralne nawiązujące do prawodawstwa niemieckiego i szwajcarskiego tę kwestię rozwiązywały identycznie (Vermeersch 1928, 358; Jone 1949, 226).

Najbardziej rozbudowane ustawodawstwo dotyczące analizowanej kwestii istniało we Włoszech i Hiszpanii. Kodeksy cywilne tych państw specjalne przepisy odnosiły do gołębi, królików i ryb. Także opracowania teologicznomoralne powstałe w tym kręgu zajmowały się zagadnieniem migracji wspomnianych gatunków zwierząt. Moraliści włoscy jednomyślnie stwierdzali, że króliki lub ryby, które migrują do innej królikarni lub stawu rybnego, stają się własnością ich właściciela. Zasada ta nie ma zastosowania jedynie w przypadku, gdy zostały one tam zwabione w sposób celowy, co należy traktować w kategorii oszustwa. Ta sama reguła odnosi się także w stosunku do gołębi, które przemieszczają się do innego gołębnika. W tym jednak przypadku konieczne jest przestrzeganie także szeregu innych przepisów prawa dotyczących gołębi wędrownych (Jone 1949, 225; da S. Mauro 1962, 232; Palazzini 1966, 667-668). Stwierdzenia te stanowią niemalże dosłowne powtórzenie przepisów prawa cywilnego (Codice Civile Italiano 1942, art. 926; Código Civil 1889, art. 612).

W przypadkach, które nie zostały uregulowane przez prawodawstwo aktualnie obowiązujące, teologowie moraliści zwykli sięgać do innych źródeł. W tym względzie korzystali chętnie z prawa rzymskiego. Przykładem może być kwestia własności zwierzęcia postrzelonego podczas polowania. Tym zagadnieniem zajmował się już Gaius Trebatius Testa żyjący w I wieku przed Chr. Twierdził, że zranione zwierzę należy do myśliwego, dopóki jest przez niego poszukiwane. Uchwycenie go w międzyczasie jest niesprawiedliwe. Jeśli jednak łowczy zaniecha poszukiwań, zwierzę to staje się ponownie rzeczą niczyją i może wejść w posiadanie kogokolwiek (da S. Mauro 1968, 230).

Na tym tle wyróżniają się jedynie podręczniki powstałe w nurcie chrystocentrycznym, na czele z monumentalnym dziełem Bernarda Häringa. Nie podejmuje on szczegółowych rozważań kwestii opisanych powyżej i wyraź- 
nie dystansuje się od uznania zwierzyny dzikiej za własność niczyją. Wskazuje bowiem, że na jej utrzymanie i opiekę państwo lub właściciel terenu łoży znaczne kwoty pieniędzy. Z tego względu powinna ona korzystać ze szczególnej ochrony (Häring 1968, 354; Wróbel 2010, 90).

\section{Zależność od prawa kościelnego (kanonicznego)}

W 1917 roku został promulgowany po raz pierwszy w historii Kościoła Kodeks prawa kanonicznego. Stał się on stosunkowo szybko jednym z podstawowych źródeł dla teologów moralistów. W temacie będącym przedmiotem niniejszego opracowania wpływ prawa kościelnego nie jest tak znaczący jak prawa świeckiego. Może jednak być on dostrzeżony w kilku aspektach. Dotyczy przede wszystkim możliwości uboju zwierząt, polowania i rybołówstwa w dni świąteczne oraz możliwości uczestnictwa osób duchownych w polowaniach.

Rozważania dotyczące wykonywania wspomnianych prac w dni świąteczne są podejmowane przez moralistów w ramach traktatu dotyczącego trzeciego przykazania Bożego. Przedmiotem odniesienia był zapis kodeksowy zabraniający podejmowania prac służebnych (Codex Iuris Canonici 1918, can. 1248) W przypadku uboju zwierząt moraliści wychodzą od stwierdzenia, że dozwolone jest $\mathrm{w}$ tych dniach przygotowywanie posiłków. $Z$ tego powodu jest możliwy także ubój, o ile jego dokonanie było niemożliwe w dniach poprzedzających. Z tego prawa można korzystać zwłaszcza w okresie letnim, co jest usprawiedliwione przez wysokie temperatury uniemożliwiające dłuższe przechowywanie żywności, chyba że przypadające święto jest połączone z bardzo uroczystym obchodem (Gaudé 1905, 563).

Moraliści nie byli natomiast zgodni co do godziwości polowań na zwierzynę leśną i ptactwo oraz rybołówstwa. W świetle jednej z opinii należy je uznać za czynności fizyczne, pracochłonne i ukierunkowane na skutki doczesne, w konsekwencji za prace służebne. Tym samym ich podjęcie sprzeciwiałoby się przepisowi prawa kościelnego. Drugie podejście, które było nieco bardziej rozpowszechnione, zakładało, że polowanie należy uznać za czynność wspólnotową i wspólnototwórczą noszącą cechy aktywności sportowej i tym samym nienaruszającą obowiązku poszanowania dnia świątecznego (Aertnys i Damen i Visser 1968, 90).

Ostatnim z poruszanych zagadnień będących pokłosiem publikacji kodeksu jest kwestia udziału osób duchownych w polowaniach. Prawo kościelne wśród wielu zajęć, które nie przystoją stanowi duchownemu, wymienia polowanie, a zwłaszcza polowanie z nagonką (Codex Iuris Canonici 1918, can. 138). Moraliści w zasadzie potwierdzają ten zakaz, nie wskazując jednak za- 
sadniczo racji uzasadniających jego istnienie. Zauważają jedynie, że rzadko uprawiane polowanie bez nagonki powinno być tolerowane (Aertnys i Damen i Visser 1968, 472). Zdaniem współczesnego komentatora, przepis ten nie miał na celu troski o humanitarne traktowanie zwierząt. Szczególne zaakcentowanie polowania $\mathrm{z}$ nagonką było podyktowane roztropnością, aby osoba duchowna biorąca udział w polowaniu przez pomyłkę nie zraniła lub nie pozbawiła życia człowieka uczestniczącego w nagonce. Prawodawstwo kościele uznawało bowiem osobę, która spowodowała śmierć lub zranienie drugiego człowieka, za niegodną pełnienia funkcji kapłańskich (Wróbel 2010, 84-85).

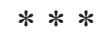

Jak łatwo można zauważyć, teologicznomoralne rozważania dotyczące relacji człowieka do zwierząt i możliwości ich wykorzystania cechuje kazuistyka i legalizm. Są one w dużej mierze powtórzeniem rozwiązań prawnych lub komentarzem do nich i skupiają się przede wszystkim na kwestii rodzajów zwierząt oraz sposobów nabywania prawa własności do nich.

Co prawda teologowie moraliści podejmują w swoich opracowaniach inne aspekty relacji człowieka wobec zwierząt, lecz ta refleksja jest zdecydowanie mniej rozwinięta. Koncentruje się ona na zagadnieniu właściwego traktowania zwierząt, przeciwdziałaniu okrucieństwu oraz etycznych aspektach doświadczeń z wykorzystaniem istot żywych (Aertnys i Damen i Visser 1968, 155-156; Rizzo 1968, 72-73). Teologowie nie potrafili jeszcze na tym etapie wskazać na ontyczne podstawy zachowań, które postulowali.

Jedynie w opracowaniach chrystocentrycznych bardzo nieśmiało dochodzi do głosu nowe spojrzenie i są formułowane nowe konkluzje (Stelzenberger 1965, 213-215; zob. więcej Smykowski 2020, 61-62). Wynika z tego, że teologia moralna niesięgająca do sobie właściwych źródeł i ograniczająca się w zasadzie do nawiązania do prawa naturalnego, prawa świeckiego i kanonicznego nie była w stanie formułować oryginalnych wniosków w tematyce będącej przedmiotem niniejszego opracowania. Dopiero odnowa soborowa z postulatem ubiblijnienia i wykorzystania w większej mierze osiągnięć innych nauk pozwoliła na podjęcie twórczego namysłu i sformułowanie katalogu powinności człowieka wobec zwierząt. Niektórzy teologowie zaczęli posługiwać się nawet kategorią praw zwierząt, nie utożsamiając ich oczywiście z podmiotowymi prawami człowieka (Wróbel 2010, 93-103). 


\title{
DEPENDENCE OF THE PRE-VATICAN II THEOLOGICAL AND MORAL THOUGHT ON LEGAL AND CANONICAL REFLECTION. ANALYSIS BASED ON THE ISSUE OF HUMAN RELATION TO ANIMALS
}

\section{Summary}

The aim of this article is to reflect on the method of argumentation undertaken by the authors of moral theology textbooks at the turn of the 19th and 20th century in the field of human relations with animals and defining the limits of their use. The analysis of a dozen or so studies representing various trends has led to the conclusion that most statements are a repetition of civil and canon law or commentary on them. Including only these data did not allow the moralists to formulate a coherent concept that would answer the more and more frequently emerging questions and doubts about the scope of man's domination over the created world.

Keywords: animals; canon law; law; moral theology

Słowa kluczowe: prawo; prawo kanoniczne; teologia moralna; zwierzęta

\section{BIBLIOGRAFIA}

\author{
Akty prawne \\ Bürgerliches Gesetzbuch. 1896. Dostęp: 25.11.2019. http://www.gesetze-im-internet.de/bgb/index. \\ $\mathrm{html}$. \\ Codex Iuris Canonici: Pii X Pontificis Maximi iussu digestus Benedicti Papae XV auctoritate pro- \\ mulgatus. 1918. Friburgi Brisgoviae: Herder. \\ Codice Civile Italiano. 1942. Dostęp: 25.11.2019. https://www.codice-civile-online.it. \\ Codice Civile Svizzero. 1907. Dostęp: 25.11.2019. https://www.admin.ch/opc/it/classified-compila- \\ tion/19070042/index.html. \\ Código Civil. 1889. Dostęp: 25.11.2019. https://www.boe.es/buscar/act.php?id=BOE-A-1889-4763.
}

\section{Opracowania teologicznomoralne}

Aertnys, Ioseph i Cornelius Damen i Ioannes Visser. 1968. Theologia moralis secundum doctrinam S. Alfonsi de Ligorio Doctoris Ecclesiae, t. 2. Torino: Marietti.

da S. Mauro, Zaccaria. 1962. Animalia. W: Dictionarium morale et canonicum, t. 3, red. Petrus Palazzini, 231-233. Romae: Officium libri catholici.

da S. Mauro, Zaccaria. 1968. Caccia. W: Dizionario di teologia morale, t. 1, red. Francesco Roberti i Pietro Palazzini 229-231. Roma: Studium Edizioni

Gaudé, Leonard. 1905. Theologia moralis. Editio nova, t. 1. Romae: Ex Typographia Vaticana.

Greniuk, Franciszek. 1998. Teologia moralna Ciała Mistycznego. W: Teologia moralna u kresu II tysiąclecia. Materiały z sympozjum KUL 1-2 grudnia 1997 r., red. Janusz Nagórny i Krzysztof Jeżyna, 75-89. Lublin: Redakcja Wydawnictw KUL.

Gury, Jean-Pierre i Juan Bautista Ferreres. 1910. Compendium theologiae moralis, t. 1. Barcinone: Eugenius Subirana. 
Häring, Bernard. 1968. Nauka Chrystusa. Teologia moralna, t. 3: Powszechne królewskie władztwo Boga. Teologia moralna szczegółowa, tłum. Jarosław Klenowski. Poznań: Pallottinum.

Jone, Eriberto. 1949. Compendio di teologia morale in relazione col Codice di Diritto Canonico col Codice Civile Italiano e col Codice Civile Elvetico. Roma-Torino: Marietti.

Jone, Heribert. 1959. Moral Theology. Westminster-Maryland: Newman Press.

Merkelbach, Benedictus Henricus. 1959. Summa theologiae moralis ad mentem D. Thomae et ad normam iuris novi, t. 2: De virtutibus moralibus. Brugis: Desclée de Brouwer et Cie.

Nodlin, Hieronymus. 1955. Summa theologiae moralis, t. 2: De praeceptis. Insbruck: Verlag Felizian Rauch.

Onida, Pietro Paolo. 2009. Animali (diritti degli). Parte giuridica. W: Enciclopedia di Bioetica e Scienza Giuridica, t. 1, red. Elio Sgreccia i Antonio Tarantino, 499-535. Napoli: Edizioni Scientifiche Italiane.

Palazzini, Petrus. 1966. Piscatio. W: Dictionarium morale et canonicum, t. 3, red. Petrus Palazzini, 667-668. Romae: Officium libri catholici.

Palazzini, Pietro. 1968. Teologia morale pre e post-conciliare, Divinitas, 12, 475-494.

Pighi, Ioannes Baptista i Angelo Grazioli. 1946. Cursus theologiae moralis ad usum scholarum theologicarum, t. 2. Verona: Scuola Tip. Vescovile Casa Buoni Fanciulli.

Prümmer, Dominicus M. 1928. Manuale theologiae moralis secundum principia S. Thomae Aquinatis in usum scholarum, t. 2. Friburgi Brisgoviae: Herder \& Co.

Rizzo, Carlo. 1968. Animali (protezione degli). W: Dizionario di teologia morale, t. 1, red. Francesco Roberti i Pietro Palazzini, 72-73. Roma: Studium Edizioni.

Smykowski, Krzysztof. 2014. Zwierzęta jako przedmiot przedsoborowej myśli teologicznomoralnej. Studia Bydgoskie, 8, 77-88.

Smykowski, Krzysztof. 2020. Kształtowanie się świadomości obowiązków człowieka wobec zwierząt w podręcznikach teologii moralnej przełomu XIX i XX wieku. Medycyna Weterynaryjna, 76(1), 59-62. DOI: 10.21521/mw.6338

Stelzenberger, Johannes. 1965. Lehrbuch der Moraltheologie. Die Sittlichkeitslehre der Königsherrschaft Gottes. Paderborn: Ferdinand Schöningh.

Szczeklik, Carolus. 1906. Casus conscientiae in praecipuas questions theologiae moralis. Tarnoviae: Typis Josephi Styrna.

Vermeersch, Arthurus. 1928, Theologiae moralis principia, responsa, consilia, t. 2, De virtutum exercitatione. Brugis: Charles Beyaert.

Wróbel, Józef. 2010. Zwierzęta i ich prawa. W: Prawa człowieka. W 60. rocznice uchwalenia Powszechnej Deklaracji Praw Człowieka. Przesłanie moralne Kościoła, red. Krzysztof Jeżyna i Tadeusz Zadykowicz, 79-103. Lublin: Wydawnictwo KUL.

Wróbel, Józef. 2016. Prawo kościelne w świetle refleksji teologicznomoralnej. Sympozjum, 20(2), 121-147.

KRZYSZTOF SmYKowSKI - kapłan diecezji bydgoskiej; doktor nauk teologicznych w zakresie teologii moralnej; adiunkt Katedry Bioetyki Teologicznej KUL; członek Zespołu Ekspertów Konferencji Episkopatu Polski ds. Bioetycznych; członek Krajowej Komisji Etycznej do spraw Doświadczeń na Zwierzętach; członek Komisji Bioetycznej przy Uniwersytecie Medycznym w Lublinie, autor opracowań z zakresu teologii moralnej i bioetyki; zainteresowania naukowe: bioetyka, moralne aspekty ekologii oraz relacji człowieka do zwierząt; e-mail: krzysztof. smykowski@kul.pl 